\title{
Diet of sympatric Barn Owls Tyto alba and Short-eared Owls Asio flammeus in an agricultural landscape in south-east Spain
}

\section{Tornugglans Tyto alba och jordugglans Asio flammeus diet där arterna samexisterar i ett jordbrukslandskap i sydöstra Spanien}

\author{
Pablo Jiménez-Nájar ${ }^{1}$ (D), Jorge Garrido-Bautista ${ }^{1, *}$ (iD), Rubén Tarifa2,3 (iD), \\ José Manuel Rivas ${ }^{4} \&$ Gregorio Moreno-Rueda' \\ 1Departamento de Zoología, Facultad de Ciencias, Universidad de Granada, 18071 Granada, Spain | najarp2009@gmail. \\ com, jorgegarrido@ugr.es, gmr@ugr.es ²Departamento Biología Animal, Biología Vegetal y Ecología, Universidad de Jaén, \\ 23071 Jaén, Spain ${ }^{3}$ Departamento de Biología, IVAGRO, Universidad de Cádiz, Campus Río San Pedro, E-11510, Puerto \\ Real, Cádiz, Spain | atricapilla.15@gmail ${ }^{4}$ Sierra Nevada Natural S. L., Centro de Visitantes El Dornajo, 18160 Güejar Sierra, \\ Granada, Spain | sierranevadanatural@gmail.com \\ *Primary author for correspondence
}

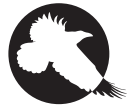

THE DIETS of the Barn Owl Tyto alba and the Short-eared Owl Asio flammeus have been extensively studied worldwide over the past few years, especially on the Iberian Peninsula. Nevertheless, very few studies have examined the diets and the trophic niche overlap in areas where these two raptor species occur in sympatry. As such, in this study we compared the diets of the Barn Owl and the Short-eared Owl inhabiting agricultural landscapes of the Vega de Granada, south-east Spain, based on pellet analysis. The diets were very similar, as both owls preyed mainly on small mammals, the Algerian Mouse Mus spretus being the prey most commonly found in pellets from both species. Although the diet of the Barn Owl was more diverse than that of the Short-eared Owl, the food niche overlap was very high, thus indicating a low interspecific trophic segregation. Despite the similarities between both diets, the frequency of the Mediterranean Pine Vole Microtus duodecimcostatus was much higher in pellets from the Barn Owl, thus suggesting that the Barn Owl may exert pest control in years when the Mediterranean Pine Vole occurs in high numbers. 


\section{Introduction}

The diet of a species varies mainly according to food availability, which is one of the main drivers of trophic niche differentiation (Schoener 1974), as well as with the interaction with other ecologically related species (e.g. Adams \& Rohlf 2000). When two species occupy the same habitat, a competition for food resources and a segregation of the trophic niches is expected to occur, especially when resources are scarce (Hardin 1960). Indeed, similar species that show allopatric distributions usually exploit the same resources (Lopes et al. 2020), whereas some degree of trophic niche segregation takes place when they live in sympatry (Gambale et al. 2020). In sympatric raptor species, interspecific competition is indeed a major source of exclusion (Newton 1979). Thus, raptors with similar diets coexist more frequently when prey diversity is higher, as this allows niche segregation (Moreno-Rueda et al. 2009). In raptors, interspecific trophic segregation can be induced both by the abundance and body size of prey, as well as the foraging strategies and activity time of the raptors (Jaksić \& Braker 1983, Leveau et al. 2004, García \& Arroyo 2005), although a transition to opportunism in sympatric raptor species may occur because of a lack of direct competition for food (Gerstell \& Bednarz 1999). The selection of different prey groups by sympatric species also explains food niche segregation processes in areas where raptor species exhibit a food niche overlap of $47-73 \%$ (e.g. Thorstrom 2000 , Navarro et al. 2003, Zhao et al. 2011, Romanowski \& Lesiński 2019).

Agricultural landscapes imply particular eco-evolutionary impacts on wild organisms (Turcotte et al. 2017). Thus, agricultural farmland composition and connectivity alter some parameters of the population dynamics of small mammals (Huitu et al. 2003, 2008, Pita et al. 2007), which may cause unpredictable population fluctuations in prey and potentially provoke changes in the trophic niche of raptor predators. A few studies have been performed on trophic niche segregation between raptors in agricultural systems (García \& Arroyo 2005, Skierczyński 2006, Milchev 2016), and many of these species, particularly nocturnal raptors, are great allies for farmers. Thus, in the same way that insectivorous birds control insect pests (Martínez-Núñez et al. 2020), nocturnal raptors sustainably control small mammal pests that damage crops (Paz-Luna et al. 2020). In fact, Barn Owls Tyto alba can base their diet exclusively on mammal agricultural pests (Kross et al. 2016). Moreover, recent evidence shows that low-impact agricultural systems may support a number of open-habitat and threatened bird species (reviewed in Wright et al. 2012).

The Barn Owl and the Short-eared Owl Asio flammeus are medium-sized nocturnal raptors (wingspan of $80-95 \mathrm{~cm}$ and $95-110 \mathrm{~cm}$, respectively) that are widely distributed across the globe (Mikkola 1983) and coexist in many geographical areas, including the Iberian Peninsula (Martí \& Del Moral 2003). The diets of these raptor species have been extensively studied worldwide. In the Mediterranean basin, small mammals (rodents and shrews) constitute the main food for these owls (e.g. Ruiz 1996, Bosè \& Guidali 2001, Bontzorlos et al. 2005, Güngör et al. 2020, Romano et al. 2020). Nevertheless, the dietary composition of Barn Owls and Short-eared Owls shows some biogeographical variations, with a variable presence of other prey types such as birds, reptiles, bats, and invertebrates in different regions (for the Barn Owl, see Pérez-Barbería 1991, Taylor 2004; for the Short-eared Owl, see Martínez et al. 1998, Djilali et al. 2016, Pozo-Zamora et al. 2017). In the Iberian Peninsula, the diets of both owl species have been extensively studied during the past several years. The Barn Owl feeds mainly on the Algerian Mouse Mus spretus and a few species of shrews (family Soricidae; Delibes et al. 1983, Vargas et al. 1988), although its trophic spectrum increases in the Mediterranean and southern regions of the Iberian Peninsula, where Barn Owls also feed on passerine birds, insects, amphibians, reptiles and bats (Herrera 1974, Herrera \& Jaksić 1980, Vargas et al. 1982, Pérez-Barbería 1991). In contrast, the Short-eared Owl shows a preference for the Common Vole Microtus arvalis when abundant (Delibes et al. 1991, Román 1995), but can also feed mainly on other rodents such as M. spretus (Calvo 1998), or complement its diet with passerines, insects, or even amphibians in the southern Iberian Peninsula (Ruiz 1996). Overall, these results suggest that the dietary diversity of these owls increases at lower latitudes within the Iberian Peninsula. 
Despite the above, very few studies have examined the diets of the Barn Owl and Short-eared Owl in areas where they occur in sympatry. In agricultural areas of Chile, for example, the diets of the two owl species overlap considerably (95\%) and the dietary diversity is quite similar, with both raptors preying on the same rodent species in similar proportions (Figueroa et al. 2009). Similarities between the diets of both owls are also found in agricultural lands in Pakistan, al- though there is a slight difference in terms of prey age (Mushtaq-Ul-Hassan et al. 2007). Finally, in the Iberian Peninsula, where the Barn Owl and Short-eared Owl coexist mainly in winter, the diet of both owls differs regarding prey proportion, with the Barn Owl feeding more frequently on shrews and amphibians than the Short-eared Owl (Román \& Ibáñez 2004).

The aim of the present study is to examine the diets of sympatric Barn Owls and Short-eared Owls and

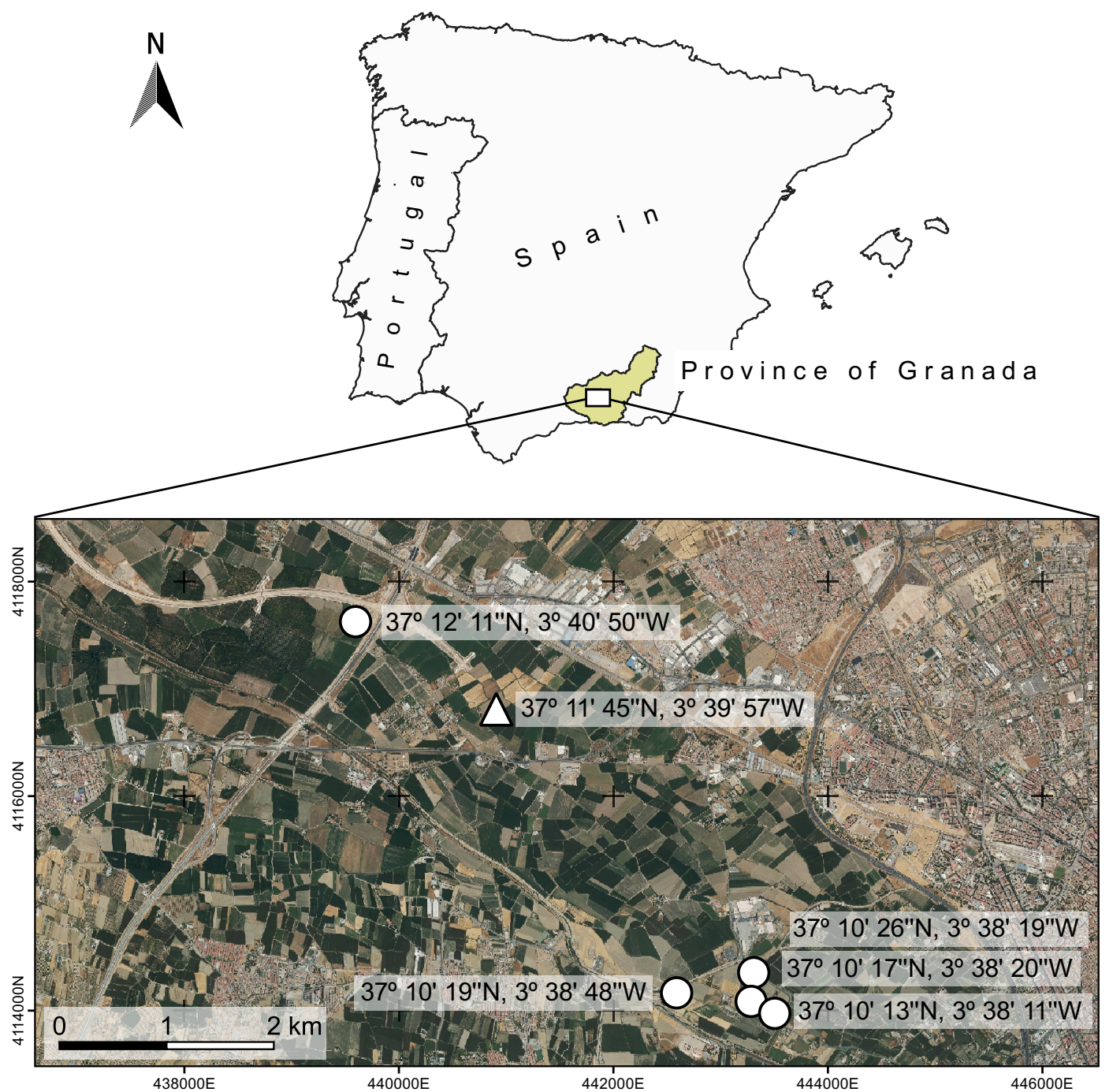

FIGURE 1. Location of the points where pellets were collected (circles: Barn Owl Tyto alba; triangle: Short-eared Owl Asio flammeus), distributed throughout the agricultural mosaic of the Vega de Granada, south-east Spain.

- Insamlingsplatser för spybollar (cirlar: tornuggla Tyto alba; triangel: jorduggla Asio flammeus), spridda I det mosaiska jordbrukslandskapet i Vega de Granada, sydöstra Spanien. 
the food niche overlap among them in an agricultural landscape of south-east Spain. We examine the prey composition of the diets and compare the dietary diversity, trophic breadth, and food niche overlap between the two owl species.

\section{Material and methods}

\section{STUDY AREA, PELLET SAMPLING, AND IDENTI- FICATION OF PREY}

We studied the diets of the Barn Owl and the Shorteared Owl in the Vega de Granada, located in the vicinity of the city of Granada in south-east Spain (Figure 1). The Vega de Granada is a fertile agricultural landscape of almost 90,000 ha, irrigated by the Genil river, and with a great diversity of crops (e.g. maize Zea mays, potatoe Solanum tuberosum, and asparagus Asparagus officinalis). Despite the agrarian intensification, natural elements-such as hedgerows and streams with native plants-are still preserved, thus making this an unusually heterogeneous farmland. The area is located at ca. $620 \mathrm{~m}$ above sea level (masl), with a Mediterranean climate (dry and hot in summer; rainy and cold in winter). The mean annual precipitation is $402.62 \pm 32.50 \mathrm{~L} \mathrm{~m}^{2} \mathrm{y}^{-1}$ and the mean temperature is $15.4 \pm 0.2^{\circ} \mathrm{C}$ (climate data for the period 2010-2019 obtained from the IFAPA agroclimatic weather station, close to the study area).

Pellets from Barn Owls $(n=128)$ were collected individually during the spring and part of summer 2014 (22 February to 31 August 2014) in five roosts (see coordinates in Figure 1; mean altitude, 621 masl). Pellets from Short-eared Owls $(n=39)$ were individually collected on 4 March and 11 March 2019 in a single roosting area $\left(37^{\circ} 11^{\prime} 45^{\prime \prime} \mathrm{N}, 3^{\circ} 39^{\prime} 57^{\prime \prime} \mathrm{W} ; 602\right.$ masl). Pellets from both raptors were stored in individual bags and the date of collection and coordinates were noted. Once in the laboratory, the pellets were broken up by immersing them in a $6 \%$ hydrogen peroxide solution (EssentQ ه) for 1-2 hours, and hair and biological matter other than bones were removed. Small mammal prey species were identified from skulls and lower jaws by using the EGAeduca dichotomous key (http://www.uhu.es/ egaeduca/), and bird prey species were identified on the basis of skulls and beaks, as described by Moreno $(1985,1986,1987)$. A Leica LED250o stereoscopic microscope was used to identify both prey types, and jaws and skulls were measured using digital callipers (accuracy: $0.01 \mathrm{~mm}$ ). As some bird prey could not be identified to the species level due to the poor condition of their skulls, they were assigned to the genus or family level. Any prey items that could not be identified were classified as "unidentified bird or mammal". Arthropod prey were assigned to the order level. Hence, prey items were sorted into Operational Taxonomic Units (OTUs), based on recognized features. All prey were identified by JGB and PJN.

\section{DIETARY AND STATISTICAL ANALYSES}

We used the Mann-Whitney U test to compare the number of prey per pellet for the two raptors, considering that the dependent variable followed a non-normal distribution. Given the imbalance between Barn Owl and Short-eared Owl pellet numbers, we used rarefaction curves (based on Hill numbers) to compare diets. Thus, we rarefied a number of pellets twice the smallest number of pellets collected per raptor (i.e. 39 pellets $\times$ 2) using incidence data. This gave an effective number of prey species, taking into account the species richness and species abundance in pellets (Chao et al. 2014). The Hill numbers framework accounts for widely used diversity measures, such as species richness $\left(\mathrm{q}_{0}\right)$, Shannon diversity $\left(q_{1}\right)$ and Simpson diversity $\left(q_{2}\right)$ (Chao et al. 2014).

We calculated Levins' Index (Levins 1968) to determine the trophic niche amplitude (D) for each raptor species according to the following equation:

$$
\mathrm{D}=\frac{1}{\sum \mathrm{P}_{\mathrm{i}}^{2}}
$$

where $P_{i}$ is the proportion of the prey item i. In addition, we calculated Pianka's Niche Overlap Index (Pianka 1973) to determine the food niche overlaps (O) between two raptor species based on degree of similarity, according to the following equation:

$$
0=\frac{\sum \mathrm{P}_{\mathrm{ij}} \times \mathrm{P}_{\mathrm{ik}}}{\left(\sum \mathrm{P}_{\mathrm{ij}}{ }^{2} \times \sum \mathrm{P}_{\mathrm{ik}}{ }^{2}\right)^{1 / 2}}
$$

where $\mathrm{P}_{\mathrm{ij}}$ is the proportion of prey item $\mathrm{i}$ in the diet of raptor $\mathrm{j}$, and $\mathrm{P}_{\mathrm{ik}}$ is the proportion of the same prey item in raptor $k$. This index ranges from o to 1 , with a value of zero indicating an absence of dietary overlap and 1 indicating a complete dietary overlap between the species. 
Descriptive statistics were calculated and statistical analyses performed using R v. 4.0.0 (R Development Core Team 2020). Plots, rarefaction analyses, and trophic niche overlap calculations were conducted using the packages ggplot2 (Wickman 2016), iNEXT (Hsieh et al. 2016), and EcoSimR (Gotelli et al. 2015), respectively. The basic statistics are given as mean \pm standard deviation (SD).

\section{Results}

A total of 167 pellets were harvested (Barn Owl: 128; Short-eared Owl: 39) and 444 prey items were removed from the pellets (Barn Owl: 307; Short-eared Owl: 137). We were able to identify 11 taxa at the species level, one at the genus level, four at the family level and one at the order level (Table 1). In addition, we were unable to identify 11 prey items (10 avian and 1 mammalian; $2.48 \%$ of the total). The number of prey per pellet ranged from one to eight individuals in the Barn Owl, and up to six in the Short-eared Owl. The average number of prey per pellet was significantly lower for the Barn Owl ( $2.40 \pm 1.41$ prey per pellet) than for the Short-eared Owl (3.51 \pm 1.17; Mann-Whitney U test, $\mathrm{z}=5.01, \mathrm{P}<0.001$; Table 1$)$. The prey number per pellet differed between the raptors depending on the prey groups: mammals appeared in higher quantity for the Short-eared Owl than for the Barn Owl (Barn Owl: $2.12 \pm 1.44$ mammals per pellet; Short-eared Owl: $3.31 \pm 1.42 ; z=4.79, P<0.001)$, but the number of birds per pellet did not differ between the two raptor species (Barn Owl: $0.27 \pm 0.46$ birds per pellet; Short-eared Owl: $0.21 \pm 0.47 ; z=1.23, P=0.32$; Table 1).

The diet of the Barn Owl in our study area consisted mainly of mammals ( $88 \%)$, followed by birds (11\%), and a limited presence of beetles ( $0.65 \%$; Table 1$)$. The Algerian Mouse constituted the main mammal prey of the Barn Owl (52\%), followed by the Mediterranean Pine Vole Microtus duodecimcostatus (almost 23\%). The main bird prey was the House Sparrow Passer domesticus, with a frequency of $3.6 \%$, with the other bird groups appearing at lower frequencies and unidentified birds representing 3.3\% of all prey (Table 1). In contrast to the Barn Owl, the diet of the Short-eared Owl showed a slightly greater predominance of mammals (94\%) and a lower presence of birds (almost 6\%; Table 1). For the Short-eared Owl, M. spretus appeared more frequently, with a rate of $78 \%$ (versus $52 \%$ in the Barn Owl), and the second most consumed prey was also M. duodecimcostatus (almost 9\%). The main bird prey was the Eurasian Tree Sparrow Passer montanus, which appeared at a rate of $2.9 \%$ (Table 1 ).

After comparing the diets of both raptor species using the rarefaction analysis (with a maximum of 78 samples), interpolation gave an estimated prey richness of 12.58 for the Barn Owl diet and 12.11 for the Shorteared Owl diet (Figure 2). Rarefaction analysis showed that the Shannon diversity was higher for the diet of the Barn Owl than of the Short-eared Owl (5.54 vs. 4.23; Figure 2). Similar results were obtained for the Simpson diversity ( 3.73 vs. 2.66). The sample coverage was 0.97 and 0.93 for the Barn Owl and the Short-eared Owl, respectively (Figure 2). Levin's index showed that the Barn Owl had a higher trophic niche breadth $(D=2.96)$ than the Short-eared Owl ( $D=1.61)$. However, Pianka's trophic niche overlap index revealed a high niche overlap between the species $(\mathrm{O}=0.939)$.

\section{Discussion}

Our results-although they should be interpreted with caution due to low pellet numbers and the sampling being performed during years and different lengths of seasons-show that, on average, pellets from Shorteared Owls contained more prey than pellets from the Barn Owl, with the former preying more frequently on small mammals. Specifically, in an agricultural landscape from south-east Spain, both owls based their diet mainly on the Algerian Mouse, although this species was more prevalent in the diet of the Short-eared Owl. The Mediterranean Pine Vole was the second most consumed prey by both raptors, although its frequency was much higher in pellets from the Barn Owl. As such, the Barn Owl may be an effective agent for controlling this vole when abundant (Kross et al. 2016, Paz-Luna et al. 2020). In contrast, birds were minor components in the diets of both owls. Lastly, although the diversity and trophic niche amplitude indices were always greater for the Barn Owl than for the Short-eared Owl, Pianka's index showed a high trophic niche overlap between the two raptors, thus suggesting a low trophic segregation between both owls.

This study included data from different years (Barn Owl and Short-eared Owl pellets were collected in 
TABLE 1. Dietary composition for Barn Owl Tyto alba and Short-eared Owl Asio flammeus in the Vega de Granada, south-east Spain. N=prey number; freq. $=$ frequency.

- Dietsammansättning för tornuggla Tyto alba och jorduggla Asio flammeus i Vega de Granada, sydöstra Spanien. N=antal.

\begin{tabular}{|c|c|c|c|c|c|c|}
\hline \multirow[b]{2}{*}{$\begin{array}{l}\text { Prey } \\
\text { Bytesdjur }\end{array}$} & \multicolumn{3}{|c|}{$\begin{array}{c}\text { Tyto alba } \\
\text { Barn Owl tornuggla }\end{array}$} & \multicolumn{3}{|c|}{$\begin{array}{c}\text { Asio flammeus } \\
\text { Short-eared Owl jorduggla }\end{array}$} \\
\hline & $\begin{array}{l}\mathrm{N} \\
N\end{array}$ & $\begin{array}{l}\text { Freq. } \\
\text { Frekvens }\end{array}$ & $\begin{array}{l}\text { Mean N/pellet } \\
\text { Medeltal/pellet }\end{array}$ & $\begin{array}{l}\mathrm{N} \\
\mathrm{N}\end{array}$ & $\begin{array}{l}\text { Freq. } \\
\text { Frekvens }\end{array}$ & $\begin{array}{l}\text { Mean N/pellet } \\
\text { Medeltal/pellet }\end{array}$ \\
\hline \multicolumn{7}{|l|}{ Mammalia | mammals däggdjur } \\
\hline \multicolumn{7}{|l|}{ Order ordning Rodentia } \\
\hline Microtus duodecimcostatus & 70 & $22.80 \%$ & 0.55 & 12 & $8.76 \%$ & 0.31 \\
\hline Mus musculus & - & - & - & 8 & $5.84 \%$ & 0.21 \\
\hline M. spretus & 161 & $52.44 \%$ & 1.26 & 107 & $78.10 \%$ & 2.74 \\
\hline Rattus rattus & 17 & $5.54 \%$ & 0.13 & - & - & - \\
\hline \multicolumn{7}{|l|}{ Order ordning Eulipotyphla } \\
\hline Crocidura russula & 21 & $6.84 \%$ & 0.16 & 1 & $0.73 \%$ & 0.03 \\
\hline Talpa occidentalis & 2 & $0.65 \%$ & 0.02 & - & - & - \\
\hline $\begin{array}{l}\text { Unidentified mammal } \\
\text { Oidentifierat däggdjur }\end{array}$ & - & - & - & 1 & $0.73 \%$ & 0.03 \\
\hline Sum mammals Summa däggdjur & 271 & $88.27 \%$ & 2.12 & 129 & $94.16 \%$ & 3.31 \\
\hline \multicolumn{7}{|l|}{ Aves | birds fåglar } \\
\hline \multicolumn{7}{|l|}{ Order ordning Galliformes } \\
\hline Coturnix coturnix & - & - & - & 1 & $0.73 \%$ & 0.03 \\
\hline \multicolumn{7}{|l|}{ Order ordning Passeriformes } \\
\hline Alaudidae & - & - & - & 2 & $1.46 \%$ & 0.05 \\
\hline Hirundo sp. & 1 & $0.33 \%$ & 0.01 & - & - & - \\
\hline Sylviidae & 5 & $1.63 \%$ & 0.04 & 1 & $0.73 \%$ & 0.03 \\
\hline Turdus merula & 1 & $0.33 \%$ & 0.01 & - & - & - \\
\hline Muscicapidae & 1 & $0.33 \%$ & 0.01 & - & - & - \\
\hline Passer domesticus & 11 & $3.58 \%$ & 0.09 & - & - & - \\
\hline P. montanus & 1 & $0.33 \%$ & 0.01 & 4 & $2.92 \%$ & 0.10 \\
\hline Motacillidae & 3 & $0.98 \%$ & 0.02 & - & - & - \\
\hline Serinus serinus & 1 & $0.33 \%$ & 0.01 & - & - & - \\
\hline $\begin{array}{l}\text { Unidentified bird } \\
\text { Oidentifierad fågel }\end{array}$ & 10 & $3.25 \%$ & 0.08 & - & - & - \\
\hline Sum birds Summa fåglar & 34 & $11.10 \%$ & 0.27 & 8 & $5.84 \%$ & 0.21 \\
\hline Insecta: Coleoptera | beetles skalbaggar & 2 & $0.65 \%$ & 0.02 & - & - & - \\
\hline Total prey items & 307 & $100 \%$ & 2.40 & 137 & $100 \%$ & 3.51 \\
\hline
\end{tabular}

2014 and 2019, respectively). A key assumption to compare the diets of the Barn Owl and the Short-eared Owl is that over-abundance of a prey species in a year did not alter the prey selection of owls. The population dynamics of several rodents of the subfamily Arvicolinae, such as voles, typically demonstrate multi-annual cyclic fluctuations, with phases occurring every two to five years (Oli 2019). However, unlike other voles, populations of the Mediterranean Pine Vole are not known to exhibit cyclic fluctuations (Guédon et al. 1992, Paradis \& Guédon 2004). Although, in other populations, the Short-eared Owl shows a clear prefe- 


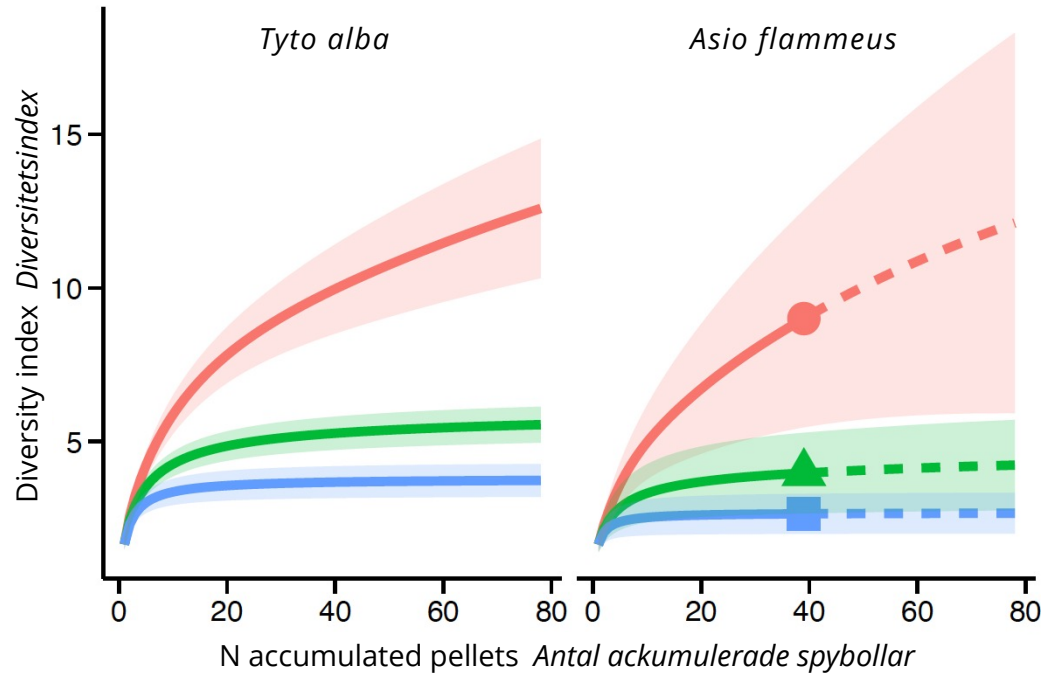

qo Species richness artrikedom

$\mathrm{q}_{1}$ Shannon diversity Shannon-diversitet

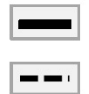

Interpolated interpolerad

Extrapolated extrapolerad

FIGURE 1. Rarefaction asymptotic curves for the diets of Barn Owls Tyto alba and Short-eared Owls Asio flammeus showing three diversity indices, estimated from 78 pellets. Note that the Barn Owl diversity indices were calculated using an interpolated method and the Short-eared Owl indices were calculated using an extrapolated method. Shaded areas represent the 95\% confidence interval. - Asymptotiska urtunningskurvor (från s.k. rarefaction analysis) för tornugglans Tyto alba och jordugglans Asio flammeus dieter, som visar tre diversitetsindex uppskattade från 78 spybollar. Notera att måtten beräknades genom interpolering för tornugglan och genom extrapolering för jordugglan.

Delibes et al. 1983, Vargas et al. 1988, Delibes et al. 1991). The murine Algerian Mouse was the most abundant prey in the diet of both owls, a finding consistent with those previously reported in the Iberian Peninsula (see Introduction).

Furthermore, this is one of the first studies examining the diet of the Short-eared Owl in the south-east region of the Iberian Peninsula, together with that reported by Ruiz (1996), since most dietary research for this raptor species has been carried out in northern latitudes (e.g. Delibes et al. 1991, Román 1995, Calvo 1998). In agricultural landscapes from southern regions of the Iberian Peninsula, the Short-eared Owl feeds mainly on Algerian Mouse, followed by Mediterranean rence for voles ( $75-81 \%$ of all prey consumed) when demographic explosions occur (Delibes et al. 1991, Román 1995), we did not observe such a preference since the frequency of Mediterranean Pine Vole in pellets of the Short-eared Owl was only $8.7 \%$. The Barn Owl, on the other hand, normally exhibits an opportunistic behaviour when selecting prey (Tores et al. 2005). This would imply that the frequency of mammals found in pellets reflects their density in the field (Andrade et al. 2016). As such, the diet composition of the Barn Owl in our study area suggests that no peak in the vole population occurred when the study was carried out, as the frequency of Algerian Mouse in pellets was much higher than that of Mediterranean Pine Vole ( $52 \%$ vs. $22 \%$ ).

Our study shows that small mammals are the most important dietary component for the Barn Owl and Short-eared Owl in farmlands in south-east Spain, as reported previously from the Iberian Peninsula (e.g.
Pine Vole (Ruiz 1996, this study). Moreover, in this geographical region, the Short-eared Owl replaces the Common Vole, which is absent in the southern half of the Iberian Peninsula, with other small mammals as its main prey, such as the Algerian Mouse, (Ruiz 1996, this study). In contrast, the Barn Owl has a similar dietary composition in farmlands in south-east Spain and other regions of the Iberian Peninsula, always showing a preference for murine and arvicoline rodents (Herrera \& Jaksić 1980, Delibes et al. 1983, Vargas et al. 1988, this study). In other Mediterranean and southern farmlands of the Iberian Peninsula, the diet of the Barn Owl is quite similar, with a preference for Algerian Mouse, followed by voles (Herrera \& Jaksić 1980, Vargas et al. 1982).

Considering a latitudinal gradient within the Iberian Peninsula, it has been reported that the diet of both owls seems to be more diverse at lower latitudes, since the Barn Owl and the Short-eared Owl complement 
their diet with birds, amphibians, reptiles, bats, or arthropods in the Mediterranean and southern regions (Herrera \& Jaksić 1980, Vargas et al. 1982, Pérez-Barbería 1991, Ruiz 1996). However, we did not observe such a diversity of prey groups. In this study, both raptors complemented their mammal-based diet with several bird species, mainly passerines, but they did not feed on a greater diversity of groups, as observed in other habitats located at similar latitudes. This could be explained by the agricultural landscape of the present study harbouring a sufficient quantity of their main prey (the Algerian Mouse), thus meaning that neither of the owls need to prey on alternative species. Indeed, the Barn Owl feeds mainly on Algerian Mouse when abundant and only switches to an ornithophagous diet when the density of Algerian Mice is low or this species is absent (Vargas et al. 1988). The Short-eared Owl, on the other hand, seems to be a specialist predator of Algerian Mouse, as it positively selects this rodent, feeding mainly on Microtus voles only when explosive demographic expansions occur (Delibes et al. 1991).

The results of the rarefaction analyses indicate that the richness of both diets did not reach an asymptote, probably because some prey (mainly birds) could not be identified to the species level. Thus, the number of rarefied pellets (78) was insufficient to estimate the exact richness of the Barn Owl and Short-eared Owl diets in this study. Despite the similarities found between the diets of the two raptors, the diversities and trophic niche breadth indices showed that the Barn Owl has a more diverse diet than the Short-eared Owl, although both diets overlap strongly when considering Pianka's trophic niche overlap index. Nonetheless, these results should be considered with caution due to low sample size for the Short-eared Owl.

Trophic segregation among raptors can be induced by the selection of different average prey body size (Jaksić \& Braker 1983, García \& Arroyo 2005), the selection of different prey groups (Thorstrom 2000, Navarro et al. 2003), or the raptors' territoriality (Jaksić 1985) or display of different foraging strategies and times of activity (Leveau et al. 2004). Differences in the time of activity between the species could explain the slight differences between their diets, as the Barn Owl is a strictly nocturnal predator (Taylor 2004) whereas the Short-eared Owl hunts mainly at twilight (Onrubia 2016). In spring, the Algerian Mouse shows peaks of activity at around twilight (Vargas et al. 1987), thus increasing its detectability for the Short-eared Owl, which would prey on it more frequently than the Barn Owl. On the other hand, the selection of different prey groups could also explain the few differences between both diets, as the Barn Owl hunts a higher diversity of bird species and mammals than the Short-eared Owl. However, our results showed that the diets of both owls strongly overlap in our study area. Other studies have found a similar diet composition in Barn Owl and Short-eared Owl when living in sympatry (Mushtaq-Ul-Hassan et al. 2007, Figueroa et al. 2009), although some trophic differentiation regarding selection of different prey groups may occur (Román \& Ibáñez 2004). Thus, the Barn Owl seems to prey on a larger diversity of species than the Short-eared Owl, such as rats, voles, amphibians, and several bird species (Román \& Ibáñez 2004, this study), although this consumption of a higher diversity of prey by the Barn Owl is not sufficient to produce a clear trophic segregation. It is plausible that the farmlands in the study area harboured abundant food resources, in terms of rodent populations, which could mean that Barn Owls and Short-eared Owls hunt the same prey species, thus leading to a high trophic niche overlap (Figueroa et al. 2009).

An understanding of the diet of raptor species in agricultural landscapes is important to determine the potential of a species to control mammal pests. The Barn Owl and the Short-eared Owl are sympatric in farmlands in south-east Spain and prey on the same mammal species. The reproductive success of owls may be enhanced because of the abundance of voles (Charter et al. 2015), thus affecting the predator-prey population dynamics. The Mediterranean Pine Vole accounts for $23 \%$ of all prey consumed by the Barn Owl, suggesting that this owl species might control voles when they constitute an agricultural pest in this region. Voles cause major damage to several field crops (Buckle \& Smith 2015) and Barn Owls have been proposed as an effective biological control service for such pest rodents through the use of artificial nest-boxes (Kross et al. 2016). Indeed, a nest-box installation treatment allowed Barn Owls to effectively reduce the vole population in several crops in another region of Spain (Paz-Luna et al. 2020), which could be complemented by other control methods (Haim et al. 2007). Hence, management 
measures aimed at improving the conservation and population sizes of Barn Owls and Short-eared Owls may be useful for the control of mammal pests, thereby reducing the use of pesticides and improving the environmental quality of farmlands and their products, and reducing costs for farmers

\section{Acknowledgements}

We are very grateful to Ángel Tórtola Sánchez and Miguel Tórtola García for their help in identifying bird prey species; without their knowledge the identification would not have been possible. We also thank the IFAPA Centro Camino de Purchil for allowing us to collect pellets at their facilities. Special thanks also to Mariola Sánchez-Cerdá for her excellent company and support during the field work around "hasking place", as well as to all the volunteers who participated in "Proyecto Sobrevolando". The comments of two anonymous referees, the editor, and the managing editor improved the manuscript.

\section{References}

Adams DC \& Rohlf FJ. 20oo. Ecological character displacement in Plethodon: biomechanical differences found from a geometric morphometric study. Proceedings of the National Academy of Sciences 97: 4106-4111. https://doi.org/10.1073/pnas.97.8.4106

Andrade A, de Menezes JFS \& Monjeau A. 2016. Are owl pellets good estimators of prey abundance? Journal of King Saud University Science 28: 239-244. https://doi.org/10.1016/j.jksus.2015.10.007

Bontzorlos VA, Peris SJ, Vlachos CG \& Bakaloudis DE. 2005. The diet of barn owl in the agricultural landscapes of central Greece. Folia Zoologica 54: 99-110.

Bosè M \& Guidali F. 2001. Seasonal and geographic differences in the diet of the barn owl in an agro-ecosystem in northern Italy. Journal of Raptor Research 35: 240-246.

Buckle AP \& Smith RH. 2015. Rodent pests and their control. CAB International, Oxfordshire, UK, and Boston, USA.

Calvo JM. 1998. Alimentación invernal de la lechuza campestre Asio flammeus en una localidad del Norte de España. Pp 467-474 in Holartic Birds of Prey (Chancellor RD, Meyburg BU \& Ferrero JJ, eds). ADENEX \& WWGBP.

Chao A, Gotelli NJ, Hsieh TC, Sander EL, Ma KH, Colwell RK \& Ellison AM. 2014. Rarefaction and extrapolation with Hill numbers: a framework for sampling and estimation in species diversity studies. Ecological Monographs 84: 45-67. https://doi. org/10.1890/13-0133.1

Charter M, Izhaki I, Leshem Y, Meyrom K \& Roulin A. 2015. Relationship between diet and reproductive success in the Israeli barn owl. Journal of Arid Environments 122: 59-63. https://doi. org/10.1016/j.jaridenv.2015.06.011

Delibes J, Hiraldo F \& Heredia B. 1991. Datos sobre la dieta invernal de la lechuza campestre (Asio flammeus) en un periodo de abundancia de topillo campesino (Microtus arvalis) en la submeseta norte (España). Ecología 5: 355-358.

Delibes M, Brunet-Lecomte P \& Máñez M. 1983. Datos sobre la alimentación de la lechuza común (Tyto alba), el búho chico (Asio otus) y el mochuelo (Athene noctua) en una misma localidad de Castilla La Vieja. Ardeola 30: 57-63.

Djilali K, Sekour M, Souttou K, Ababsa L, Guezoul O, Denys C \& Doumandji S. 2016. Diet of short-eared owl Asio flammeus (Pontoppidan, 1763) in desert area at Hassi El Gara (El Golea, Algeria). Zoology and Ecology 26: 159-165. https://doi.org/10.1080/2 1658005.2016.1184907

Dupal TA \& Chernyshov VM. 2013. Small mammals in the diets of the long-eared owl (Asio otus) and short-eared owl (A. flammeus) in the south of western Siberia. Russian Journal of Ecology 44: 397-401. https://doi.org/10.1134/S1067413613040048

Figueroa RA, Rau JR, Mayorga S, Martínez DR, Corales ES, Mansilla A \& Figueroa R. 2009. Rodent prey of the barn owl Tyto alba and short-eared owl Asio flammeus during winter in agricultural lands in southern Chile. Wildlife Biology 15: 129-136. https://doi. org/10.2981/08-005

Gambale PG, da Silva MR, Oda FH \& Bastos RP. 2020. Diet and trophic niche of two sympatric Physalaemus species in Central Brazil. South American Journal of Herpetology 17: 63. https://doi. org/10.2994/SAJH-D-17-00100.1

García JT \& Arroyo BE. 2005. Food-niche differentiation in sympatric Hen Circus cyaneus and Montagu's Harriers Circus pygargus: food-niche differentiation in sympatric harriers. Ibis 147: 144-154. https://doi.org/10.1111/j.1474-919x.2004.00377.x

Gerstell AT \& Bednarz JC. 1999. Competition and patterns of resource use by two sympatric raptors. Condor 101: 557-565. https://doi.org/10.2307/1370185

Gotelli NJ, Hart EM \& Ellison AM. 2015. EcoSimR: null model analysis for ecological data. R package version o.1.0.

Guédon G, Paradis E \& Croset H. 1992. Capture-recapture study of a population of the Mediterranean pine vole (Microtus duodecimcostatus) in Southern France. Mammalian Biology 57: 364-372.

Güngör U, Bacak E \& Beşkardeş V. 202o. Short-eared owl (Asio flammeus)'s winter diets in northwestern Turkey (Thrace). Forestist 71: 40-44. https://doi.org/10.5152/forestist.2020.20021

Haim A, Shanas U, Brandes O \& Gilboa A. 2007. Suggesting the use of integrated methods for vole population management in alfalfa fields. Integrative Zoology 2: 184-190. https://doi. org/10.1111/j.1749-4877.2007.00054.x

Hardin G. 196o. The competitive exclusion principle. Science 131: 1292-1297. https://doi.org/10.1126/science.131.3409.1292

Herrera C. 1974. Régimen alimenticio de Tyto alba en España sudoccidental. Ardeola 19: 359-394.

Herrera C \& Jaksić FM. 1980. Feeding ecology of the barn owl in central Chile and southern Spain: a comparative study. Auk 97: $760-767$.

Hsieh TC, Ma KH \& Chao A. 2016. iNEXT: an R package for rarefaction and extrapolation of species diversity (Hill numbers). Methods in Ecology and Evolution 7: 1451-1456. https://doi. org/10.1111/2041-210X.12613

Huitu O, Laaksonen J, Klemola T \& Korpimäki E. 20o8. Spatial dynamics of Microtus vole populations in continuous and fragmented agricultural landscapes. Oecologia 155: 53-61. https:// doi.org/10.1007/s00442-007-0885-x

Huitu O, Norrdahl K \& Korpimäki E. 2003. Landscape effects on temporal and spatial properties of vole population fluctuations. Oecologia 135: 209-22o. https://doi.org/10.1007/soo442-002-1171-6

Jaksić FM. 1985. Towards raptor community ecology: behavior bases of assemblage structure. Journal of Raptor Research 19: 107-112.

Jaksić FM \& Braker HE. 1983. Food-niche relationships and guild 
structure of diurnal birds of prey: competition versus opportunism. Canadian Journal of Zoology 61: 2230-2241. https://doi.org/10.1139/ z83-295

Kross SM, Bourbour RP \& Martinico BL. 2016. Agricultural land use, barn owl diet, and vertebrate pest control implications. Agriculture, Ecosystems and Environment 223: 167-174. https://doi.org/10.1016/j. agee.2016.03.002

Leveau LM, Leveau CM \& Pardiñas UFJ. 2004. Trophic relationships between white-tailed kites (Elanus leucurus) and barn owls (Tyto alba) in Southern Buenos Aires province, Argentina. Journal of Raptor Research 38: 178-181.

Levins R. 1968. Evolution in changing environments. Princeton University Press, Princeton.

Lopes CM, De Barba M, Boyer F, Mercier C, Galiano D, Kubiak BB, Maestri R, Silva Filho PJS, Gielly L, Coissac E, Freitas TRO \& Taberlet P. 2020. Ecological specialization and niche overlap of subterranean rodents inferred from DNA metabarcoding diet analysis. Molecular Ecology 29: 3143-3153. https://doi.org/10.1111/ mec. 15549

Martí R \& Del Moral JC. 2003. Atlas de las aves reproductoras de España. Dirección General de Conservación de la Naturaleza-Sociedad Española de Ornitología, Madrid, Spain.

Martínez DR, Figueroa RA \& Ocampo CL, 1998. Food habits and hunting ranges of short-eared owls (Asio flammeus) in agricultural landscapes of southern Chile. Journal of Raptor Research 32: 111-115.

Martínez-Núñez C, Rey PJ, Manzaneda AJ, Tarifa R, Salido T, Isla J, Pérez AJ, Camacho FM \& Molina JL. 2020. Direct and indirect effects of agricultural practices, landscape complexity and climate on insectivorous birds, pest abundance and damage in olive groves. Agriculture, Ecosystems and Environment 304: 107145. https://doi. org/10.1016/j.agee.2020.107145

Mikkola H. 1983. Owls of Europe. T \& AD Poyser, Calton, UK.

Milchev B. 2016. Dietary comparison of coexisting barn owl (Tyto alba) and eagle owl (Bubo bubo) during consecutive breeding seasons. Animal Biology 66: 219-228. https://doi. org/10.1163/15707563-00002499

Moreno E. 1985. Clave osteológica para la identificación de los passeriformes ibéricos. I. Aegithalidae, Remizidae, Paridae, Emberizidae, Passeridae, Fringillidae, Alaudidae. Ardeola 32: 295-377.

Moreno E. 1986. Clave osteológica para la identificación de los passeriformes ibéricos. II. Hirundinidae, Prunellidae, Sittidae, Certhiidae, Troglodytidae, Cinclidae, Laniidae, Oriolidae, Corvidae, Sturnidae, Motacillidae. Ardeola 33: 69-129.

Moreno E. 1987. Clave osteológica para la identificación de los passeriformes ibéricos. III. Muscicapidae. Ardeola 34: 243-273.

Moreno-Rueda G, Pizarro M, Ontiveros D \& Pleguezuelos JM. 2009. The coexistence of the eagles Aquila chrysaetos and Hieraaetus fasciatus increases with low human population density, intermediate temperature, and high prey diversity. Annales Zoologici Fennici 46: 283-29o. https://doi.org/10.5735/086.046.0405

Mushtaq-Ul-Hassan M, Ghazi RR \& Nisa N-U. 2007. Food preference of the short-eared owl (Asio flammeus) and barn owl (Tyto alba) at Usta Muhammad, Baluchistan, Pakistan. Turkish Journal of Zoology 31: 91-94.

Navarro J, Sánchez-Zapata JA, Carrete M \& Botella F. 2003. Diet of three sympatric owls in steppe habitats of Eastern Kazakhstan. Journal of Raptor Research 37: 256-258.

Newton I. 1979. Population ecology of raptors. T \& AD Poyser, Berkhamsted, UK.

Oli MK. 2019. Population cycles in voles and lemmings: state of the science and future directions. Mammal Review 49: 226-239. https://doi.org/10.1111/mam.12156

Onrubia A. 2016. Búho campestre - Asio flammeus. In Enciclopedia
Virtual de los Vertebrados Españoles (Salvador A \& Morales MB, eds). Museo Nacional de Ciencias Naturales, Madrid, Spain.

Paradis E \& Guédon G. 2004. Demography of a mediterranean microtine: the Mediterranean pine vole Microtus duodecimcostatus. Oecologia 95: 47-53. https://doi.org/10.1007/BFoo649505

Paz-Luna A, Bintanel H, Viñuela J \& Villanúa D. 2020. Nest-boxes for raptors as a biological control system of vole pests: high local success with moderate negative consequences for non-target species. Biological Control 146: 104267. https://doi.org/10.1016/j. biocontrol.2020.104267

Pérez-Barbería FJ. 1991. Influencia de la variación latitudinal en la contribución de los murciélagos (Chiroptera) a la dieta de la lechuza común (Tyto alba). Ardeola 38: 61-68.

Pianka ER. 1973. The structure of lizard communities. Annual Review of Ecology and Systematics 4: 53-74. https://doi.org/10.1146/ annurev.es.04.110173.000413

Pita R, Beja P \& Mira A. 2007. Spatial population structure of the Cabrera vole in mediterranean farmland: the relative role of patch and matrix effects. Biological Conservation 134: 383-392. https://doi. org/10.1016/j.biocon.2006.08.026

Pozo-Zamora GM, Brito J, García R, Alarcón I \& Cadena-Ortiz H. 2017. Primer reporte de la dieta del búho orejicorto Asio flammeus (Strigiformes: Strigidae) en Pichincha, Ecuador. Revista Ecuatoriana de Ornitología 1: 1-17. https://doi.org/10.18272/reo.voi1.463

$\mathrm{R}$ Development Core Team 2020. R: A language and environment for statistical computing. R Foundation for Statistical Computing, Vienna, Austria.

Román J. 1995. Alimentación de la lechuza campestre en la Submeseta Norte, durante el periodo reproductor. Doñana: Acta Vertebrata 22: $115-119$.

Román J \& Ibáñez F. 2004. Alimentación invernal de la lechuza campestre (Asio flammeus) y de la lechuza común (Tyto alba) en un área marismeña de Doñana. Anuario ornitológico de Doñana (1999/2001) 1: 211-216.

Romano A, Séchaud R \& Roulin A. 2020. Global biogeographical patterns in the diet of a cosmopolitan avian predator. Journal of Biogeography 47: 1467-1481. https://doi.org/10.1111/jbi.13829

Romanowski J \& Lesiński G. 2019. Comparing trophic niches of sympatric raptors in agricultural landscape in Central Poland. Polish Journal of Ecology 67: 331-338. https://doi.org/10.3161/150522 49PJE2019.67.4.005

Ruiz R. 1996. Variaciones geográfica y temporal en la dieta de la lechuza campestre (Asio flammeus) en Europa. Doñana: Acta Vertebrata 23: 5-20.

Schoener TW. 1974. Resource partitioning in ecological communities. Science 185: 27-39. https://doi.org/10.1126/science.185.4145.27

Skierczyński M. 20o6. Food niche overlap of three sympatric raptors breeding in agricultural landscape in Western Pomerania region of Poland. Buteo 15: 17-22.

Taylor I. 2004. Barn owls: predator-prey relationships and conservation. Cambridge University Press, Cambridge, UK.

Thorstrom R. 200o. The food habits of sympatric forest-falcons during the breeding season in Northeastern Guatemala. Journal of Raptor Research 34: 196-202.

Tores M, Motro Y, Motro U \& Yom-Tov Y. 2005. The barn owl-A selective opportunist predator. Israel Journal of Zoology 51: 349-360. https://doi.org/10.1560/7862-9E5G-RQJJ-15BE

Torres JC, Teta P \& De la Sancha NU. 2014. Presas del búho campestre (Asio flammeus) en un agrosistema subtropical de Paraguay. Nuestras Aves 59: 24-27.

Turcotte MM, Araki H, Karp DS, Poveda K \& Whitehead SR. 2017. The eco-evolutionary impacts of domestication and agricultural practices on wild species. Philosophical Transactions of the Royal 
Society B 372: 20160033. https://doi.org/10.1098/rstb.2016.0033 Vargas JM, Miguel E \& Blasco M. 1982. Estudio estacional comparativo del régimen alimentario de Tyto alba Scolopi en Fuentepiedra de Málaga y El Padul de Granada (España). Miscellania Zoologica 6: 95-102.

Vargas JM, Palomo LJ \& Antúnez A. 1987. Ciclo diario de actividad de Mus spretus Lataste 1883 en el sur de la Península Ibérica. Pp 121-130 in Mamíferos y helmintos (Sans-Coma V \& Mas-Coma S, eds). Ketres Editora, Barcelona, Spain.

Vargas JM, Palomo LJ \& Palmquist P. 1988. Predación y selección intraespecífica de la lechuza común (Tyto alba) sobre el ratón moruno (Mus spretus). Ardeola 35: 109-123.

Wickman H. 2016. ggplot2: elegant graphics for data analysis.
Springer-Verlag, New York, USA.

Williford D, Woodin MC \& Skoruppa MK. 2011. The winter diet of short-eared owls in subtropical Texas: do southern diets provide evidence of opportunism? Journal of Raptor Research 45: 63-70. https://doi.org/10.3356/JRR-10-40.1

Wright HL, Lake IR \& Dolman PM. 2012. Agriculture-a key element for conservation in the developing world. Conservation Letters 5: 11-19. https://doi.org/10.1111/j.1755-263X.2011.00208.x

Zhao W, Shao M-Q, Song S \& Liu N-F. 2011. Niche separation of two sympatric owls in the desert of Northwestern China. Journal of Raptor Research 45: 174-179. https://doi.org/10.3356/JRR-10-41.1

\section{Svensk sammanfattning}

Under senare år har födoval hos tornuggla Tyto alba och jorduggla Asio flammeus studerats över hela världen, speciellt på Iberiska halvön. Trots det har man sällan undersökt dieterna hos dessa arter i områden där de förekommer tillsammans. När två arter förekommer i samma miljö förväntas detta leda till konkurrens om födan, med en uppdelning av nischen som följd (speciellt om det är brist på föda). Här har vi jämfört dieterna hos tornuggla och jorduggla i ett område med jordbrukslandskap i sydöstra Spanien (Vega de Granada, figur 1).

Studien baseras på analys av spybollar $(n=128$ för tornuggla; $\mathrm{n}=39$ för jorduggla) som samlats in manuellt under våren och sommaren 2014 samt 2019, vid 6 platser. Spybollarna löstes upp i en lösning med väteperoxid och annat material än ben avlägsnades. Bytesdjuren artbestämdes genom granskning i stereolupp av skallar och underkäkar (däggdjur) samt skallar och näbbar (fåglar). Leddjur (Arthropoda) bestämdes till ordning.

Totalt 444 bytesdjur kunde bestämmas ur de 167 undersökta spybollarna. Vi kunde bestämma 11 taxa till artnivå, ett till släkte, fyra till familj och ett till ordning (tabell 1). Ytterligare 11 bytesdjur (10 fåglar och 1 däggdjur) kunde ej bestämmas. Antalet bytesdjur per spyboll varierade mellan 1 och 8 (medel 2,40) hos tornuggla och 1-6 (medel 3,51) för jorduggla. Det fanns i genomsnitt fler däggdjur per spyboll för jorduggla (medel 3,31) än för tornuggla (medel 2,12) medan det inte var någon signifikant skillnad mellan arterna för făglar (medel o,27 för tornuggla, o,21 för jorduggla).

Vi fann att de båda ugglearterna har väldigt likartad diet, bestående främst av mindre däggdjur ( $88 \%$ hos tornuggla och $94 \%$ hos jorduggla). Algerisk husmus Mus spretus var det vanligaste bytet i spybollar från båda arterna ( $78 \%$ hos jorduggla och $52 \%$ hos tornuggla). Den vanligaste fågelarten bland bytesdjuren var pilfink (3,9\% hos tornuggla och 2,9\% hos jorduggla), medan förekomsten av arthropoder var väldigt låg. Även om dieten hos tornuggla var mer varierad än hos jorduggla (Shannons diversitetsindex $=5,54$ respektive 4,23; figur 2), så fanns det ett stort överlapp i födoval, vilket indikerar en låg grad av trofisk segregering mellan arterna. Trots likheterna i val av bytesdjur, så förekom provencegransork Microtus duodecimcostatus i betydligt högre utsträckning i spybollar från tornuggla ( $52 \%$ jämfört med $9 \%$ hos jorduggla).

Avsaknaden av tydlig nischuppdelning mellan de två ugglearterna kan möjligen förklaras med skillnader i födosöksbeteende, där tornugglan är en strikt nattaktiv predator medan jordugglan främst är aktiv under skymning och gryning. En viktig begränsning med studien är att data för de två arterna samlades in olika år (2014 för tornuggla och 2019 för jorduggla). Så det går inte att utesluta att eventuella skillnader i diet mellan arterna, som observerats här, beror på temporal variation $\mathrm{i}$ tillgång på olika typer av bytesdjur. Eftersom provencegransork vid höga tätheter kan utgöra ett skadedjur för jordbruket, skulle man utifrån våra resultat kunna spekulera i om tornuggla kan vara viktig för att minska sådan skada, genom att kontrollera sorkpopulationen. Man har i andra studier observerat att uppsättning av holkar för tornuggla kan minska mängden sorkar i jordbrukslandskapet. 


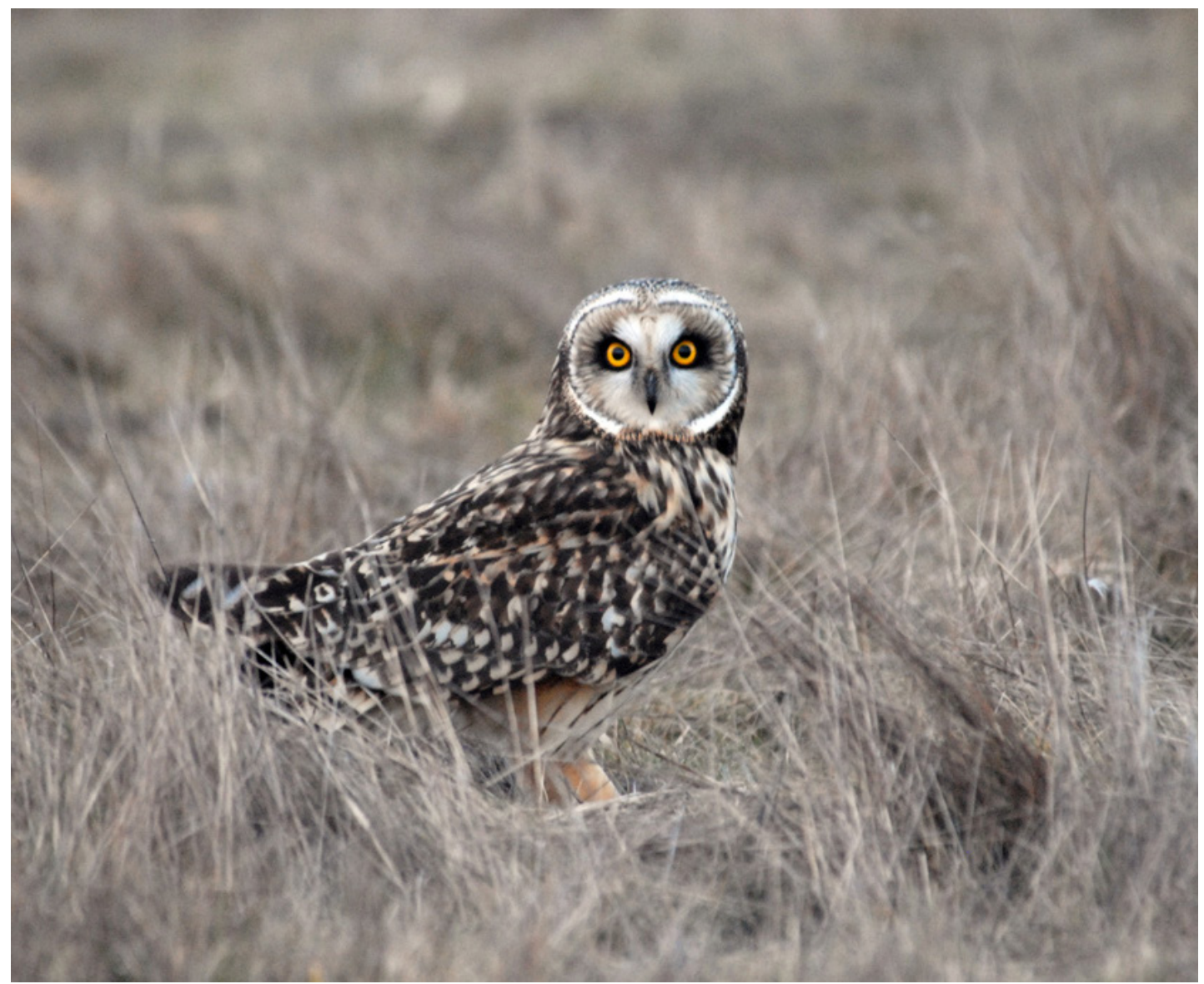

Short-eared Owl (jorduggla) Asio flammeus. @ Dan Dzurisin (CC-BY-NC-ND 2.0).

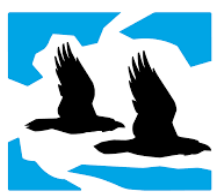

Birdlife Sverige

Ornis Svecica (ISSN 2003-2633) is an open access, peer-reviewed scientific journal published in English and Swedish by BirdLife Sweden. It covers all aspects of ornithology, and welcomes contributions from scientists as well as non-professional ornithologists. Accepted articles are published at no charge to the authors. Read papers or make a submission at os.birdlife.se.

Ornis Svecica (ISSN 2003-2633) är en fritt tillgänglig granskad vetenskaplig tidskrift som ges ut på svenska och engelska av BirdLife Sverige. Den täcker ornitologins alla områden och välkomnar bidrag från såväl forskare som icke-professionella ornitologer. Accepterade uppsatser publiceras utan kostnad för författarna. Läs uppsatser eller skicka in ditt bidrag på os.birdlife.se. 